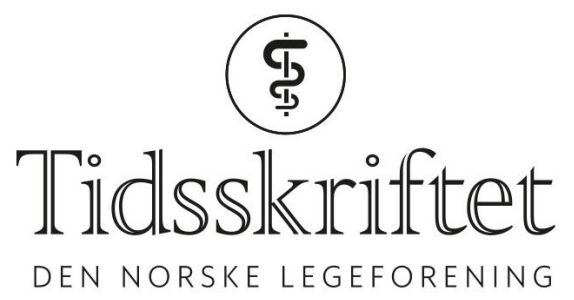

\title{
Debatt om AD/HD-behandling er velkommen
}

KOMMENTAR

\section{TROND VELKEN}

E-post:velt@siv.no

Trond Velken er overlege og spesialist i psykiatri og barne- og ungdomspsykiatri ved Sykehuset i Vestfold.

Ingen oppgitte interessekonflikter.

Lea argumenterer i sin kommentar for at det ikke er grunn til å så tvil om AD/HDlegemidlenes effekt, forutsatt regelmessig oppfølging i spesialisthelsetjenesten. Lea avviser også at det er noen kunnskapskrise, og slår fast at $\mathrm{AD} / \mathrm{HD}$ «forstås som en meget sammensatt, kompleks reguleringsforstyrrelse der gener i samspill med miljøfaktorer fører til påvisbare endringer i hjernen og ulike kliniske mønstre». Det er en fare for at dette leses med for stort fokus på at det kan foreligge en forstyrret hjerne som årsak til uro og konsentrasjonsvansker. Lea refererer til påvist «mindre volum i flere sentrale hjerneavsnitt hos barn og voksne med AD/HD». Mange mener forfatterne av den refererte analysen gikk for langt i å beskrive slike volumforskjeller som typisk ved AD/HD. I virkeligheten var det beskjedne effektstørrelser og stort overlapp mellom AD/HD og kontrollgruppen. De fleste med $\mathrm{AD} / \mathrm{HD}$ har en strukturelt normal hjerne, og mange mennesker uten $\mathrm{AD} / \mathrm{HD}$ har mindre volum i aktuelle hjerneavsnitt enn gjennomsnittet for AD/HD-gruppen. Ved å referere slike funn på gruppenivå etterlates et feilaktig inntrykk av at man nærmer seg en forklaring på vanskene vi ser hos den enkelte. $\mathrm{AD} / \mathrm{HD}$ gruppen er så heterogent sammensatt at vi kanskje burde nøye oss med å beskrive de uro og konsentrasjonsvansker vi ser, og ikke gi inntrykk av at vi forstår hva vi har funnet ved å gi det en syndrombenevnelse.

Jeg ønsker også å utfordre Leas beskrivelse av at legemidlenes effekt er tilfredsstillende dokumentert. Lea refererer til Dundee-modellen og «meget gode langtidsresultater». Dundee-modellen kan vi lære av når det gjelder systematikk i oppfølging over tid og kartlegging av bivirkninger. Den har imidlertid ingen kontrollerte betingelser som avklarer om mangeårig medikamentbehandling er gunstig. $96 \%$ av pasientene som var inkludert ved siste publiserte datapunkt, brukte legemiddel, og vi vet ikke nok om de pasientene som ikke lenger er inkludert i oppfølging, og heller ikke hvordan forløpet ville være om man brukte mindre legemidler. Legemidlene innvirker på sentrale signalstoffer som er involvert i en lang rekke prosesser i kroppen og hjernen utover atferd og oppmerksomhetsfunksjoner, og vi skulle gjerne visst mer om hva det betyr at vi påvirker disse systemene over mange år. Kanskje særlig i en hjerne som modnes og utvikles. Funn fra MTA-studien tyder på at eksponering for AD/HD-medikamenter over flere år kan gi signifikant veksthemming (1), og vi vet fortsatt ikke om det skyldes redusert næringsinntak, innvirkning på veksthormon eller annet. En redusert slutthøyde er isolert sett kanskje 
ingen avgjørende ulempe, men vi er ellers lært opp til å tenke at en organisme som trives vokser, og hva er den reduserte veksten eventuelt en mark $\emptyset$ for?

Mange pasienter opplever nytte av medikamentbehandling. Men vi trenger å drøfte begrensningene i kunnskapsfeltet, og derfor er Vogt \& Lundes kronikk veldig velkommen.

\section{LITTERATUR:}

1. MTA Cooperative Group. Young adult outcomes in the follow-up of the multimodal treatment study of attention-deficit/hyperactivity disorder: symptom persistence, source discrepancy, and height suppression. J Child Psychol Psychiatry 2017; 58: 663 - 78. [PubMed][CrossRef]

Publisert: 16. mars 2018. Tidsskr Nor Legeforen. DOI: 10.4045/tidsskr.18.0184

(C) Tidsskrift for Den norske legeforening 2020. Lastet ned fra tidsskriftet.no 